\title{
通水性のある円柱に作用する流体力の特性*
}

\author{
渡 部 英夫*1, 庵 原 昭 夫*1, 橋 本 弘 之*1
}

\section{Hydraulic Characteristics of a Circular Cylinder with a Permeable Wall}

\author{
Hideo WATANABE, Akio IHARA and Hiroyuki HASHIMOTO
}

\begin{abstract}
Experiments were performed with two circular cylinders whose walls were porous and permeable in order to investigate the effects of flow of water through the wall. Each cylinder was made of bronze sintered compact, available as a sintered metallic filter. It had an outside diameter of 30 $\mathrm{mm}$, wall thickness of $2 \mathrm{~mm}$ and nominal filter size of $2 \mu \mathrm{m}$ and $20 \mu \mathrm{m}$, respectively. Force coefficients and pressure distributions of the test cylinders were measured over the Reynolds number $1.1 \times 10^{5} \sim$ $4.4 \times 10^{5}$ and were compared with those of the same porous cylinders into which another circular cylinder, an "inner cylinder" with a solid wall, was inserted to obstruct such a through-flow. The measured results showed that the drag coefficients and the root-mean-square values of the fluctuating lift coefficients of the test cylinder equipped with the inner cylinder were smaller than those with the through-flow. This was caused by the increase in the effective surface roughness and the altered pressure distribution because of the permeability of the cylinder wall. The increase in the drag coefficient was accompanied by the decrease in the Strouhal number of the fluctuating lift, and vice versa.
\end{abstract}

Key Words : External Flow, Fluid Force, Pressure Distribution, Circular Cylinder, Permeability, Surface Roughness, Transition, Strouhal Number

\section{1. 緒}

円柱周りの流れは，流体機械や水理構造物にしばし ば見られる鈍頭物体周りの流れを理解する基礎となる ので, 従来数多くの研究が積み重孙られており、現在 屯なお多くの研究がなされている网元化(1)(2)。著者らも さきに水流中に置かれた円柱の表面から微細な気泡を 吹き出し，それに作用する流体力の特性を実験的に解 明した(3)。その際に用いた供武円柱は、球形のプロン ズ粉末粒子を円筒型に焼結したもので、円柱壁はポー ラスで通水性を有している。この円柱壁が有する通水 性のために、気泡を吹き出さない完全に濡れた状㱝に おけるその周りの流れは, 通水性のない壁面を持つ円 柱周りの流れとは異なっている,すなわち, 円柱周り の圧力分布によって円柱外部から内部へ(またはその逆 に) 円柱壁を通り抜けて流入・流出する流れが誘起され ていると考えられる兆候を示した。例えば、同程度の

* 平成 5 年 8 月 21 日 流体工学部門講演会において講演, 原 稿受付 平成 5 年 10 月 13 日.

*1 正只, 東北大学流体科学研究所 ( $-980-77$ 仙台市青葉区片平 2-1-1).
相対粗さを持つ通水性のない円柱に比べて大きな抗力 と変動揚力が計測された。よって本研究においては, 円 柱壁を通り抜ける流れを円柱内部に通水性のない円筒 を择入して阻止した場合と，それを取り除いた場合と を比较することによって, 円柱壁の通水性が円柱の揚・ 抗力, ストローハル数、圧力分布などに及ぼす影響を 明かにすることを試みた。

\section{主な婄号}

$$
\begin{aligned}
C_{D} & : \text { 抗力係数 }=2 D /\left(\rho U_{\infty}{ }^{2} d l\right) \\
C_{L} & : \text { 揚力係数 }=2 L /\left(\rho U_{\infty}{ }^{2} d l\right) \\
C_{p} & : \text { 圧力係数 }=2\left(p_{\theta}-p_{\infty}\right) /\left(\rho U_{\infty}{ }^{2}\right) \\
d & : \text { 供試円柱の直径 }(\mathrm{m}) \\
D, L & : \text { 抗力, 揚力 }(\mathrm{N}) \\
f & : \text { 周波数 }(1 / \mathrm{s}) \\
H & : \text { 流路高さ }(\mathrm{m}) \\
d_{r} & : \text { ブロンズ焼結体のブロンズ粒子径 }(\mathrm{m}) \\
k_{s} & : \text { Nikuradse の砂粒粗さの高さ }(\mathrm{m}) \\
\ell & : \text { 供試円柱の流路幅方向の長さ }(\mathrm{m}) \\
p & : \text { 圧力 }(\mathrm{Pa}) \\
R e & : \text { レイノルズ数 }=U_{\infty} d / \nu
\end{aligned}
$$


表 1 実験装置の主要寸法と実験条件

\begin{tabular}{|c|c|c|}
\hline Water tunnel & Closed-loop type & \\
\hline Test section & Height $(H) 305 \mathrm{~mm}$, Width & $100 \mathrm{~mm}$ \\
\hline Free-stream velocity & $5 \sim 15 \mathrm{~m} / \mathrm{s}$ & \\
\hline Turbulence intensity & About $0.1 \%$ at $10 \mathrm{~m} /$ & \\
\hline Pressure & Free from cavitation occu & rence \\
\hline Water temperature & $286 \sim 302 \mathrm{~K}$ & \\
\hline Reynolds number $(R e)$ & $1.1 \sim 4.4 \times 10^{5}$ & \\
\hline \multirow{4}{*}{ Test cylinder } & Outside diameter $(d)$ & $30 \mathrm{~mm}$ \\
\hline & Length $(\ell)$ & $100 \mathrm{~mm}$ \\
\hline & Aspect Ratio $(\ell / d)$ & 3.3 \\
\hline & Tunnel blockage ratio $(d / H)$ & $9.8 \%$ \\
\hline
\end{tabular}

表 2 ポーラス円柱の諸元

\begin{tabular}{|c|c|c|}
\hline Name & $\begin{array}{c}2 \mu \mathrm{m} \\
\text { porous cylinder }\end{array}$ & $\begin{array}{c}20 \mu \mathrm{m} \\
\text { porous cylinder }\end{array}$ \\
\hline Nominal filter size & $2 \mu \mathrm{m}$ & $20 \mu \mathrm{m}$ \\
\hline $\begin{array}{c}\text { Diameter of } \\
\text { bronze particle }\left(d_{r}\right)\end{array}$ & $50 \pm 3 \mu \mathrm{m}$ & $200 \pm 20 \mu \mathrm{m}$ \\
\hline Permeability & $0.5 \times 10^{-7} \mathrm{~cm}^{2}$ & $2.0 \times 10^{-7} \mathrm{~cm}^{2}$ \\
\hline$d_{r} / d$ & $170 \times 10^{-5}$ & $670 \times 10^{-5}$ \\
\hline $0.55\left(d_{r} / d\right)^{(6)}$ & $90 \times 10^{-5}$ & $370 \times 10^{-5}$ \\
\hline
\end{tabular}

$S t:$ ストローハル数 $=f d / U_{\infty}$

$U_{\infty}:$ 一様流の速度 $(\mathrm{m} / \mathrm{s})$

$\nu:$ 水の動粘性係数 $\left(\mathrm{m}^{2} / \mathrm{s}\right)$

$\rho:$ 水の密度 $\left(\mathrm{kg} / \mathrm{m}^{3}\right)$

$\theta:$ 円柱の前方肢点から测った周方向角度 (度)

添学

mean：時間平均值

$\mathrm{rms}$ ：時間変動成分の二乗平均值

$\theta$ ：角度 $\theta$ におる値

'(prime) : 変動成分

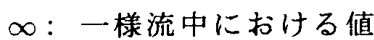

\section{2. 実験装置および方法}

実鈳には東北大学流体科学研究所の大形高速回流実 験室に設置されている密閉型回流水槽を用いた。詳細 は文献(4)(5)に䁚り，表 1 に回流水槽と供試円柱の主要寸 法と主な実験条件を示した。

供試円柱は, Ihara et al. ${ }^{(3)}$ が円柱の流力特性に及ぼす 微細気泡の表面吹き出しの影響について実験を行った 際に用いたもの之同一で，通水性のある円筒壁 (厚さ $2 \mathrm{~mm})$ を持つ 2 本の供試円柱は，それぞれ公称ろ過精度 $2 \mu \mathrm{m} と 20 \mu \mathrm{m}$ の焼結ブロンズ製円筒型フィルタエレメン トを利用して製作したものである。これより後，各円 柱をその素材の公称ろ過精度に因んで “ $2 \mu \mathrm{m}$ ポーラス 円柱”および “ $20 \mu \mathrm{m}$ ポーラス円柱”と呼ぶことにする。

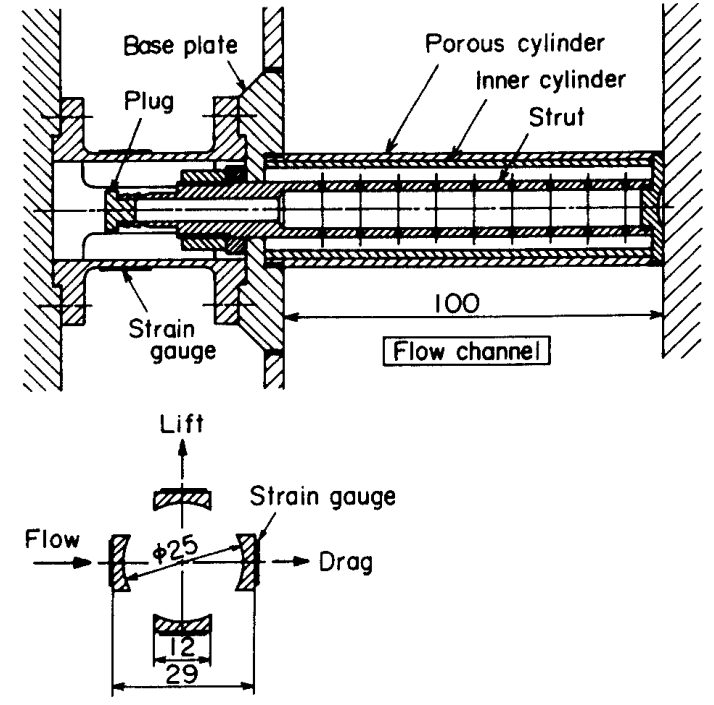

図 1 揚・抗力計測用ポーラス円柱および力センサ

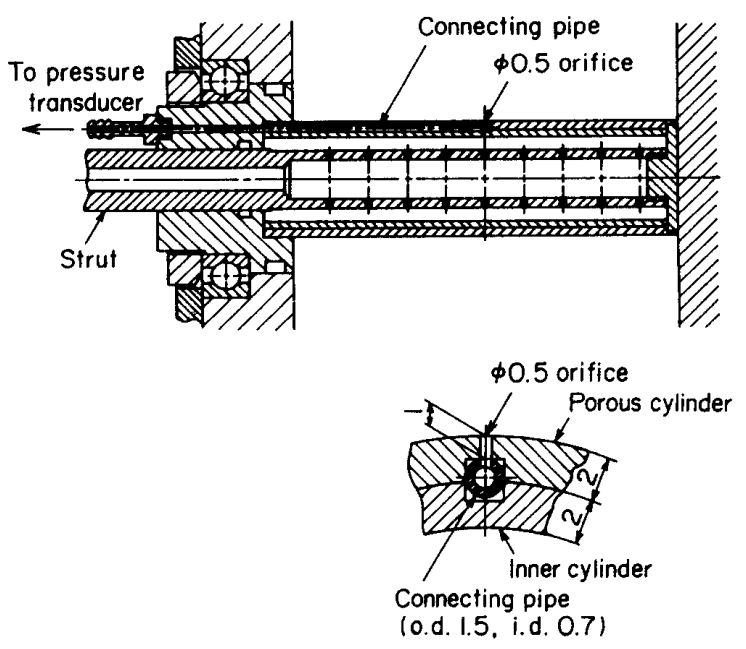

図 2 压力分布計测用ポーラス円柱

各ポーラス円柱の諸元を表 2 に示す．通水性は, メー カのカタログデータから算出した。その值は，比較的 細かい砂地の通水性の範囲(7)にある。また，比較のた めに，通水性のない表面が滑らかな（中心線平均粗さ $0.2 \mu \mathrm{m})$ 黄銅製 “滑面円柱”を用いた実験も行った。

各円柱に作用する流体力は, 図1に示すひずみゲー ジ式の揚・抗力測定用バランスを用いて測定した。図 はポーラス円柱を取り付けた状態のもので，円柱中心 には補強用の支柱が通っている。センサ部はステンレ ス鋼製である。ひずみゲージの防水のため，ゲージお よびそれとリード線との接続部をエポキシ樹脂系接着 剂で薄くコーティングした後, シリコンゴムでリード 線も含めて広く覆った。

ポーラス円柱内部には, 図 1 に示すように円柱内径 


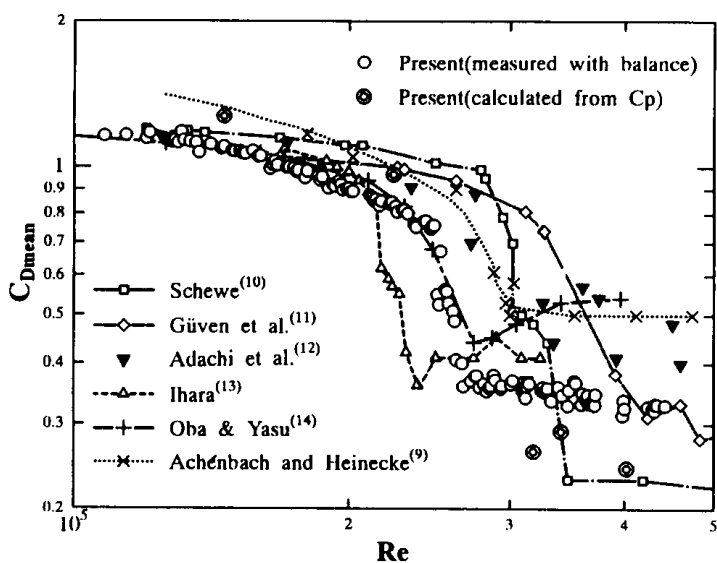

図 3 抗力係数 $C_{D \text { mean }}$ のレイノルズ数 $R e$ による変化 (既存テータとの比較)

表 3 実検条件の比較

\begin{tabular}{|c|c|c|c|c|c|c|}
\hline Auther(s) & Fluid & $\begin{array}{l}\text { Aspect } \\
\text { ratio }\end{array}$ & $\begin{array}{l}\text { Blockage } \\
\text { ratio(\%) }\end{array}$ & $\begin{array}{c}\text { Blockage } \\
\text { correction }^{(s)}\end{array}$ & $\begin{array}{c}\text { Turbulence } \\
\text { intensity(\%) }\end{array}$ & Method \\
\hline $\begin{array}{l}\text { Achenbach and } \\
\text { Heinecke }{ }^{(9)}\end{array}$ & Air & 3.38 & 16.4 & Not done & 0.45 & $C_{p}$ \\
\hline Schewe ${ }^{(10)}$ & Air & 10.0 & 10.0 & Not done & less than 0.4 & Balance \\
\hline Güven et al. ${ }^{(11)}$ & Air & 3.08 & 17.8 & Done & 0.2 & $C_{p}$ \\
\hline Adachi et al. ${ }^{(12)}$ & Air & 10.0 & 10.0 & Done & 0.37 (max.) & $C_{\mathrm{p}}$ \\
\hline Ihara ${ }^{(13)}$ & Water & 2.5 & 15.4 & Not done & 0.72 & Balance \\
\hline Oba \& Yasu ${ }^{(14)}$ & Water & $3.3,1.7$ & $5.0,10.0$ & Done & & $C_{p}$ \\
\hline Present & Water & 3.3 & 9.8 & Not done & 0.1 & Balance \\
\hline
\end{tabular}

にその外径が等しい黄銅製の山筒(厚さ $2 \mathrm{~mm}$ )を挿入し て，ポーラス円柱壁を通り抜ける流れを阻止した。通 り拔け流れを許した実験を行う場合にはこの円筒（以 後、“内筒”と呼ぶことにする)を取り除いた。

図 2 には压力分布計測用のポーラス円柱を示す. 長手 方向中央には直径 $0.5 \mathrm{~mm}$ の測压孔 1 個が設けられてい る。測圧孔は，図の下方に示すように，ポーラス壁内側 に压力伝送用の銅管を埋め込み，ポーラス壁とその銅 管壁を貫通する穴をドリルで開けることによって設け た．円柱は支柱を軸として自由に回転させることがで き，それによって円柱の全周にわたって表面圧力分布を 測定することができる．このような構造では，ポーラ ス壁内の通水性のために，測圧孔を介して計測される 压力にはその周辺の压力分布の影響が含まれ，したが って計測される圧力分布は，流体力を計測した場合の それとは若干異なっていると考えられるが，測定結果 の考察によると，その影㖕は定性的な議論には十分に 耐え得る程度のわずかなものであった。

\section{3. 結果と考察}

\section{$3 \cdot 1$ 抗力係数}

$3 \cdot 1 \cdot 1$ 既存結果との比較 本実験における計測 結果の妥当性を調べるため, 滑面円柱の抗力係数の レイノルズ数による変化を, 他の研究者の計測結果と

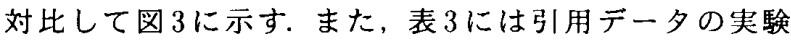
条件の主なものを示す.

よく知られているように，円柱の流力特性は実験条 件によって異なる。図においても亜臨界領域(流れ領域

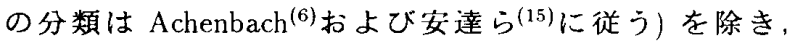
臨界レイノルズ数および抗力係数の做が研究者によっ て違っている。しかしそれと流路閒塞効果の補正の有 無，アスペクト比，抗力の計測方法（表面压力を積分 する方法，バランスを用いて直接計測する方法）など との間に相関は認められないようである。また，本実 験では,バランスによる計測值 (○印) と $C_{p}$ より求めた 值 (@印) との大小関俰が, 臨界レイノルズ数の前後で 逆転している。その理由に関し， $C_{p}$ より求まるのは圧 力抵抗のみであること， $C_{p}$ を流路中央でしか計測して いないこと, どちらの值についても流路閉塞効果を補 䜣していないこと，などを考虑して実験データを検討 したが，その理由を明かにすることはできなかった。・-・. 方，本実験を除き一様中の乱れ度が小さいほど，臨界 レイノルズ数が大きくなっている．本実験における臨 界レイノルズ数は，乱れ度が約 $0.1 \%$ とさいにもかか わらず、乱れ度が $0.37 \% の$ 安達ら ${ }^{(12)} や 0.45 \%$ A Achenbach and Heinecke ${ }^{(9)} の も の よ り$ 若干小さくなっている。これ には作動流体，円柱端の隙間の大きさ，円柱の支持方 法など，表に掲げた以外の実験条件の違いが影響して いると考えられる。したがって，既存データとの橄密な 比較は不可能であるが，本実験においても亜臨界領域 から超臨界領域にかけての円柱の典型的な流力特性が 得られており，また臨界点から超臨界領域の初期にお ける抗力係数の值は他の実験結果の中間にあって，本 実験における計測結果はおおむね妥当であると考えら れる。

3・1・2 通水性の影謩 図 4 に内筒の有無による レイノルズ数 $(R e)$ - 抗力係数 $\left(C_{D \text { mean }}\right)$ 曲線の変化を滑 面円柱のそれと比較して示す.

Achenbach $^{(6)}$ や安達ら ${ }^{(15)}$ は， 円柱周りの流れに及ぼ す表面粗さの影響を実験的に調べ，表面粗さが增大 すると臨界レイノルズ数が減少し，その点における 抗力係数が増大するとともに，超臨界から極超臨界 領域における抗力係数が増大することを明らかにして いる。両ポーラス円柱の表面はブロンズ粒子を寄せ集 めた粗面之なっているため，上述の粗面円柱の場合と 同じく滑面円柱に比へて境界層の発達が早く，先に触 れた Achenbach ${ }^{(6)} の$ 流れ領域の分類に従えば，内筒の 


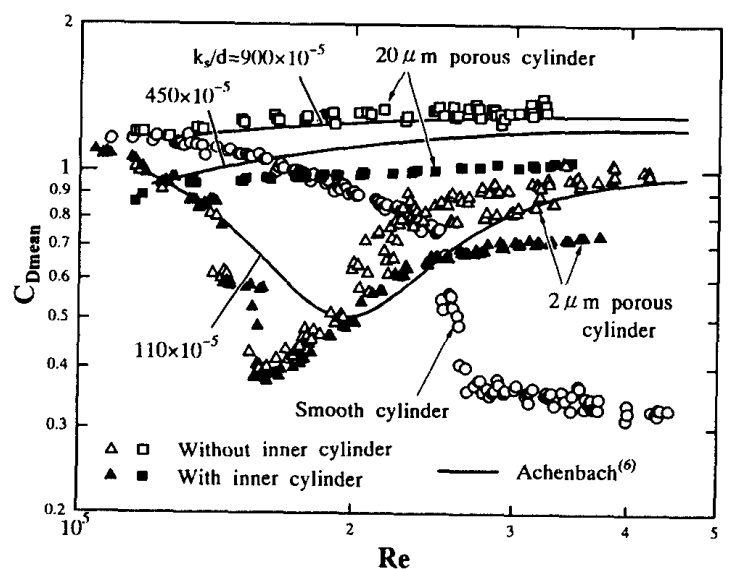

図 4 時間平均抗力係数 $C_{D \text { mean }}$ のレイノルズ数 Re による変 化に及ぼす内筒の影響

有無にかかわらず $20 \mu \mathrm{m}$ ポーラス円柱の特性は極超臨 界領域にあり， $2 \mu \mathrm{m}$ ポーラス円柱のそれは遷移領域 から極超臨界領域の初期にある. 図4中の実線はその Achenbach ${ }^{(6)}$ の実験結果で，表面粗さによる抗力係数 の変化を示したものである．k衫は等価砂粒粗さ(Nikuradse's sand-grain roughness)，dは円柱直径である。他に も粗面円柱の抗力係数を実測した例は多い(11)(15)(16)が, 等価砂粒粗さを彼のように検定によって求めたものは 知見せず，彼の実験結果との比較において各々の実験 結果に考察を加えているので，ここでもそれに做うこ とにする。

Achenbach ${ }^{(6)}$ によれば，直径 $d_{r}$ の球形の粗さ要素を円 柱表面に貼付した場合の等価砂粒粗さ $k_{s}$ は， $d_{r}$ にでは なく $0.55 d_{r}$ に相当する. 一方, Schlichting ${ }^{(17)} の$ 矩形ダク トでの実験によれば， $k_{s}=0.627 d_{r}$ となる．表 2 には $k_{s}=$ $d_{r}$ とした場合とAchenbach の提唱する $k_{s}$ を用いた場合 の両方の相対粗さ $\left(k_{s} / d\right)$ を算出しておいた.

前節に述へたように笅密な比較はできないが，図 4 において内筒を㧴入している両ポーラス円柱の極超臨 界領域での抗力係数の值を Achenbach のものと対比す ると，それらは $k_{s}=d_{r}$ ではなく， $k_{s}=0.55 d_{r}$ るいは $k_{s}=0.627 d_{r}$ である相対粗さを持つ粗面円柱のそれに近 いと考えられる。

内筒を除去してポーラス壁を通り抜ける流れを許す 亡, 極超臨界領域にある $20 \mu \mathrm{m}$ ポーラス円柱の場合, 抗力係数が䄪 $40 \%$ 增大する.同様に， $2 \mu \mathrm{m}$ ポーラス円 柱の超臨界領域の終期から極超臨界領域の初期におけ る抗力係数も，内筒を除去することによって同程度增 大する．その場合の相対粗さは，表 2 および図 4 から $k_{s}=d_{r}$ として算出したものの方が妥当である。したが ってこの流れ領域では，円柱壁に通水性が生ずると寒

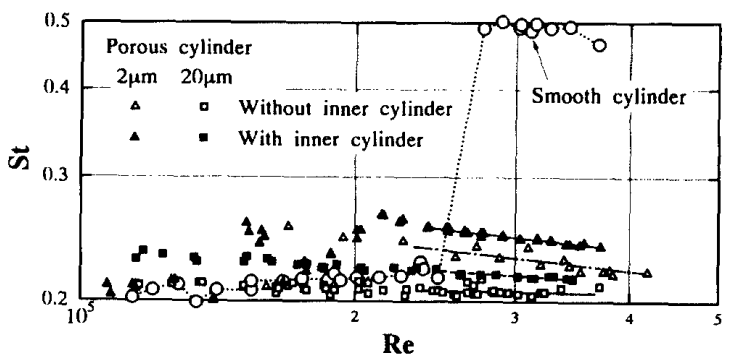

図 5 ストローハル数 St のレイノルズ数Reによる変化に及 ぼす内筒の影響

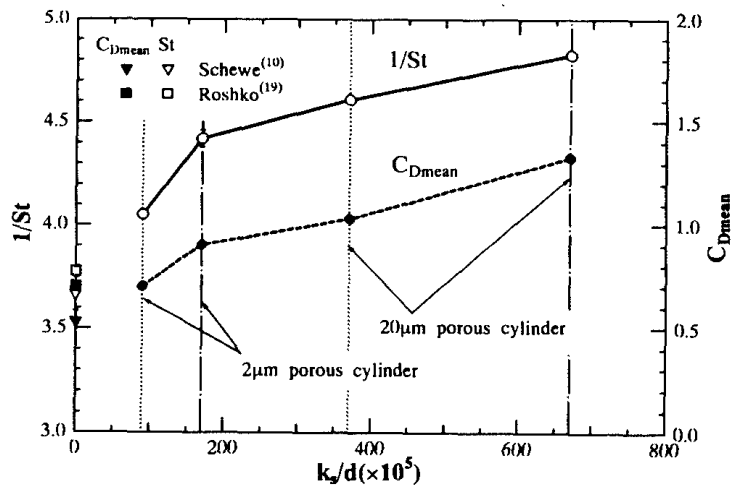

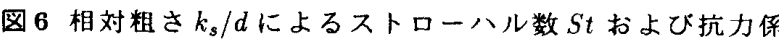
数 $C_{D \text { mean }}$ の変化

質的な表面粗さが增大すると考えられる。

一方，後述する压力分布の計測結果からは，内筒 の除去による抗力係数の増大は，はく離点の前進に伴 う後流幅の搪大によるとの見方も可能である。すなわ ち，通り抜け流れがある場合には，それによって円柱 表面の回り込み流れが阻止されるために後流幅が増大 し，抗力係数の增大が引き起こされると考えられる。 この様な流れの様相は，久保ら(18)の流入・流出スりッ 卜を有する円筒内の流れを水素気泡法によって可視化 した結果にも現われているように見受けられる。

しかしながら， $2 \mu \mathrm{m}$ ポーラス円柱の遷移領域から超 臨界領域の初期の領域では，内筒を除去しても抗力係 数および臨界レイノルズ数はほ之んど変化しない，

$3 \cdot 2$ ストローハル数 図 5 には変動揚力のスペ クトルピークから算出したストローハル数Stのレイ， ルズ数 Reによる変化を示す．抗力係数とは逆に，内筒 を除去すると超臨界領域から極超臨界領域における $S t$ の値が若干減少している.

安達ら(15)は，極超臨界領域におけるストローハル数 $S t$ が粗さのみによって決まる一定值を取り，表面粗さ が大きいほど $S t$ が小さくなること見出している．ま た, Achenbach and Heinecke ${ }^{(9)}$ は, 計測結果はテータの散 らばりの範囲内にあるとして結論を保留しているが, 安達ら ${ }^{(15)}$ 之同様の傾向を示すデータを提出している. 


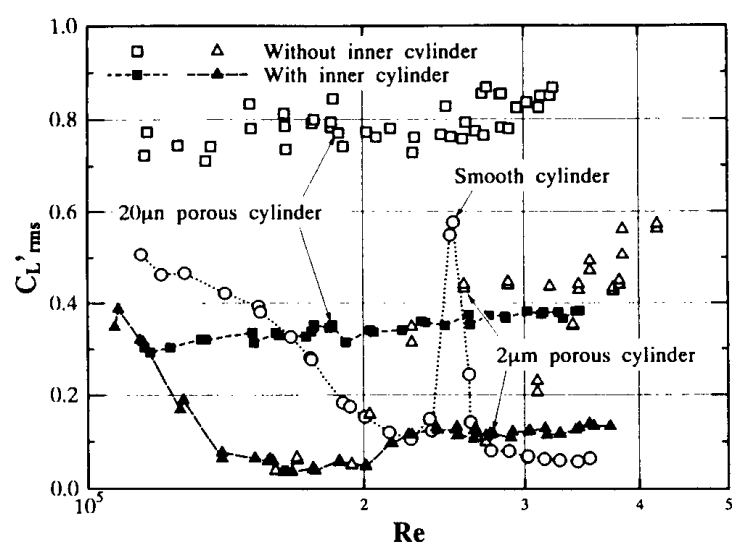

图 7 㤎動揚力係数の $\mathrm{rms}$ 值 $C_{L_{\mathrm{rms}}}^{\prime}$ のレイノルズ数 Re による 変化に及ぼす内筒の影響

したがって，本実験でのストローハル数の計測結果か らも，抗力係数 (図4)の場合と同じく，内筒を除去する 之超臨界領域から極超臨界領域における実質的な表面 粗さが增大するものと考えられる。

一方，抗力係数とストローハル数との間には，抗力 係数が增大すればストローハル数が減少し，抗力係数 が減少すればストローハル数が增大するという相関の あることが知られている(19). このことを検証するた め, 図6に超臨界領域の終期から極超臨界領域におけ る抗力係数とストローハル数の逆数 $\left(1 / S_{s}\right)$ の, 相対粗 さ $\left(k_{s} / d\right)$ による変化を示す．相対粗さは $3 \cdot 1 \cdot 2$ 節に述 べた考察に基づき，内筒を挿入した場合(縦の点線で示 す) は $k_{s}=0.55 d_{r}$ として，内筒を除去した場合（縦の一 点鎖線で示す) は $k_{s}=d_{r}$ として算出した，ストロ一八 ル数および抗力係数はレイノルズ数が $2.5 \times 10^{5}$ 以上に おける平均值である。また，参考のために，滑面円柱

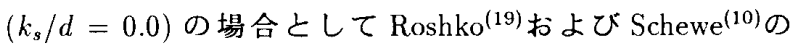
極超臨界領域における実験值を平均した值も記入して ある。

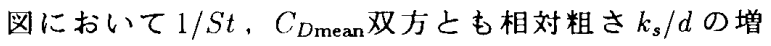
大とともに単調に增大している。このことは $3 \cdot 1 \cdot 2$ 節に述べた $k_{s}$ の見皘りがほぼ妥当であって, それを用

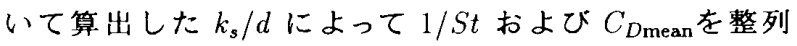
させることができることを示している，そして，実験 点を結んだ二本の曲線がほぼ平行を保って変化してい て，前述した抗力係数とストローハル数との相関が相 対粗さ $k_{s} / d$ を変化させた場合にも存在することが認め られる。

$3 \cdot 3$ 揚力変動と压力分布眼 7 に揚力変動の $\mathrm{rms}$ 值 $C_{L_{\mathrm{rm} \mathrm{s}}}^{\prime}$ のレイノルズ数による変化を示す. 滑面円柱の 遥移領域に見られる鋭いピークは，双安定な揚力の発

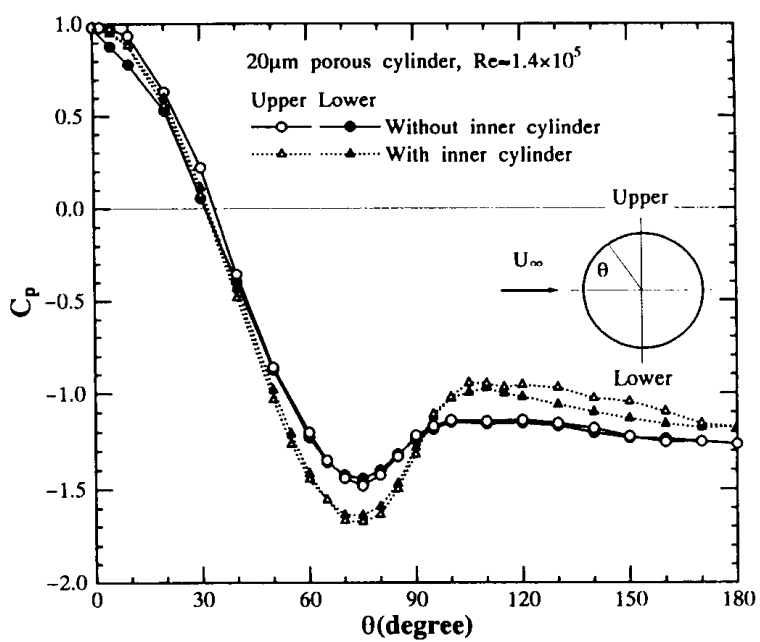

図8 王力分布に及ぼす内筒の影響

生・消滅によるものである(20)，抗力係数 (図 4) の場合 と同様，内筒の除去によって超臨界領域の終期より大 きなレイノルズ数の領域で, 揚力の変動が大幅に増大 している。

図8には内筒の除去によってすべての特性值が変化 した極超臨界領域における圧力分布を示す，内筒を除 去することによって最小压力係数が上昇し，はく離点 が約 $10^{\circ}$ 上流に移動し，背压が下がっている。

これらの変化は，前述した $(3 \cdot 1 \cdot 2$ 節) ような抗 力係数の変化に対応しており，内筒を除去することに よって壁面に通水性が生じたために，円柱からの瀜の 流出に対応して円柱上下面の最小圧力点付近に円柱壁 を通って流出入する流れが発生し，これがはく離点を 上流側に移動させ, 放出される渦の強さを増大させて いる(21)(22)ことによって引き起こされたものと考えられ る。

\section{4. 結 論}

一様な水流中に置かれたポーラスな円筒壁をもつ円 柱の流力特性に及ぼす壁面の通水性の影響を明かにす る目的で，焼結ブロンズ製の中空门柱を供試物体とし て実験を行い，次のような結論を得た。

（1）ポーラス円柱内部に通水性のない内筒を抙入し て円柱壁を通り抜ける流れを阻止した場合に比べ，そ れを除去して通水性を付与した場合には，超臨界領域 から極超臨界領域における抗力係数が增大する，また， 揚力の変動も增大する。

(2) その原因は，(a) 内筒を除去することによって円柱 表面の実質的な粗さが増大すること，(b) 円柱まわりの 王力分布が変化して最小压力係数が上昇し，はく離点 が上流に移動し，背圧が低下すること，(c) 壁面に生じ 
た通水性のために，渦の流出に対応して最小圧力点付 近に円柱壁を通って流出入する流れが発生し，これが はく離点を上流側に移動させ, 放出される渦の強さを 增大させること，などであろうと推量される。

(3) 本実験の場合にも抗力係数が增大するとストロ 一八ル数が減少するという，滑面円柱の場合と同様の 抗力係数とストローハル数との相関が認められた.$$
\text { 文献 }
$$

(1) West, G. S. and Apelt, C. J., Measurements of Fluctuating Pressures and Forces on a Circular Cylinder in the Reynolds Number Range $10^{4}$ to $2.5 \times 10^{5}, \mathrm{~J}$. Fluids and Structures, 7(1993), pp. 227-244.

(2) 福富純一郎・中瀬敬之・潼川三左男, テーパ円柱および段 付円柱の後流渦, 機論 (B), 59-559(1993), pp.684-690.

(3) Ihara, A., Watanabe, H., and Hashimoto, H., Hydraulic Forces Acting on a Circular Cylinder with Surface Source of Minute Air Bubbles and Its Citation Characteristics, Trans. ASME, J. Fluids Engng., 115 -2(1993), pp. 275-282.

（4）村井等・庵原昭夫・菱沼信夫・濱谷剛, 增速翼列のキャビ テーション性能に及ぼす流速の影響，東北大学速研報告， 58(1987), pp. 51-93.

（5）渡部英夫·庵原昭夫・橋本弘之，前縁付近からの微細気泡 吹出しを伴うだ円柱の流力特性，機論 (B), 59-561(1993), pp. 1457-1464.

(6) Achenbach, E, Influence of Surface Roughness on the Crossflow Around a Circular Cylinder, J. Fluid Mech., 46-2(1971), pp. 321-335.

(7) Streeter, V. L., Handbook of Fluid Dynamics, 1st ed., (1961), 16-8, McGraw-Hill.

(8) Allen, H. J. and Vincenti, W. G., Wall Interference in a Two-Dimensional-Flow Wind Tunnel, With Consideration of the Effect of Compressibility, NACA Technical Report No 782(1944).

(9) Achenbach, E. and Heinecke, E., On Vortex Shedding From Smooth and Rough Cylinders in the Range of Reynolds Num- bers $6 \times 10^{3}$ to $5 \times 10^{6}$, J. Fluid Mech., 109(1981), pp. 239-251.

(10) Schewe, G., On the Force Fluctuations Acting on a Circular Cylinder in Crossflow From Subcritical up to Transcritical Reynolds Numbers, J. Fluid Mech., 133(1983), pp. 265-285.

(11) Güven O., Farell, C, and Patel, V. C., Surface-Roughness Effects on the Mean Flow Past Circular Cylinders, J. Fluid Mech., 98-4(1980), pp. 673-701.

（12）安達勤・松内一雄・松田諭・河合達雄, 高レイノルズ数に おける円柱まわりの流九と抵抗，機論 (B), 51-461(1985)， pp. 295-299.

（13）糜原昭夫，キャビテーションによる非定常流体力に及ぼ す後退角の影䪪 (第 1 報, 後退角を有する内柱キャビテー ションの非定常流体力), 東北大学速研報告, 53(1984), pp. $17-31$

（14）大場利三郎・安昭八，円柱キャビテーションの動特性(特 に2 種の振動について)，機論 (B),46-402(1980), pp. 197205

（15）安達勤・小野博基・松内一雄・河合達雄・長哲夫, 高レイ ノルズ数領域における円柱まわりの流れ(表面粗さの影 䋨), 機論 (B), 55-511(1989), pp. 685-691.

(16) Nakamura, Y. and Tomonari, Y., The Effects of Surface Roughness on the Flow Past Circular Cylinders at High Reynolds Numbers, J. Fiuid Mech., 123(1982), pp. 363-378.

(17) Schlichting, H., Boundary-Layer Theory, 7th Edition, McGraw-Hill Book Company, 1979, p. 624.

（18）久保忠延・池田钽彦・土屋良明, 流入・流出スリットを有す 万円筒内の流れの可視化, 可視化情報, 13-Suppl. 2(1993), pp. 43-46.

(19) Roshko, A., Experiments on the Flow Past a Circular Cylinder at Very High Reynolds Number, J. Fluid Mech., 10(1961), pp. 345-356.

(20) Schewe, G., Sensitivity of Transition Phenomena to Small Perturbations in Flow Round a Circular Cylinder, J. Fluid Mech., 172(1986), pp. 33-46

（21）五十風保,スリットのある円柱まわりの流れ特性(第 1 報, 流れの制御とフローパターン), 機諭, 43-372(1977), pp. 2974-2984.

（22）川田裕郎ほか(編著)，流量計測ハンドブック，日刊工業新 聞社, 1979, pp. 357-359. 